\title{
A Study on the Teaching Mode of Dance Teaching in Normal Universities
}

\author{
Can Zhang \\ Huaiyin Normal University, Huaian Jiangsu, 223000, China
}

Keywords: dance in higher normal universities, teaching theory, course teaching mode

\begin{abstract}
Dance course in higher normal universities has its unique scientific and particularity, the traditional teaching mode fails to meet the requirements of higher normal dance teaching and the development of the higher normal dance teaching theory. Thus, the teaching mode must be reformed and innovated in order to meet society's need for higher normal talents. This paper studies the construction of the teaching mode of higher normal dance course from the perspective of teaching theory.
\end{abstract}

\section{Introduction}

Higher normal school is the important place to develop primary and secondary school teachers for the society, in today's universal access to quality education, teachers' comprehensive quality and improve the comprehensive ability directly affects the level and quality of basic education in our country. But the current our country small and medium-sized students dance skills areas teachers strength weak, investigate its root again far higher normal dance teaching quality cannot be improved, higher normal dance teaching to improve teaching quality, must be "teaching", "learning", "with" be in harmony are an organic whole, built in accordance with the law of higher normal dance teaching, the reasonable course teaching mode.

\section{Significance of Higher Normal Education Sets Dance Course}

\subsection{It Will Help Promote the Development of Education for Children and Primary and Secondary Schools in China}

The concept of scientific development is centered on heat, promote people's all-round and healthy development, let the children to be fully healthy development and strong young is the mission of education workers at all levels and task, guided by the scientific concept of development of reform and development of children and adolescent education, comprehensive and objective analysis of the campus education present situation, the innovation management idea, build perfect education mechanism, create a good learning environment for students, education overall, coordinate sustainable development is the direction of the current reform of preschool and primary and secondary school education. Normal colleges is the important place to cultivate qualified teachers for the society, opening of dance course in normal colleges is the higher normal colleges and universities in view of the quality education reform of courses, help to improve the students' professional attainment and comprehensive quality, for preschool and primary and secondary school education in the right direction development, create a good learning environment for students' healthy growth has important influence.

\subsection{It Laid the Foundation for the Implementation of Education}

The main purpose of education is to train high-quality education talents with all-round development. Students' professional ability and comprehensive quality and the full-time compulsory education wangle standard " is directly related to the implementation, are all factors influencing the quality education can be the key to success, therefore, dance foundation education reform, higher normal education to dance must be accordingly adjusted. Because our country education training 
target is not clear, resulting in higher normal students' art education ability, social practice ability has been unable to fully meet basic education and the social construction of spiritual civilization in China's need for higher normal personnel skills and literacy. Higher education belongs to the normal dance courses professional education, the basis of in terms of education connotation, dance teaching teachers training should be comprehensive, pay attention to quality education in teaching, constant innovation and reform teaching contents and teaching methods, lay solid foundation for the students who love dance, laying a foundation for the further development of quality education for the country.

\subsection{It has Positive Impetus to the Professional Development of Teachers}

Traditional education problems and the requirements of teachers' quality of education have limitations, quality education popularization of education and teachers' comprehensive quality has put forward the new requirements, updating the education content, the method of innovation education is the idea of teachers need higher normal colleges and universities also want to keep up to renew the idea of talent training, teacher open field of vision, improve their comprehensive qualities can teach the students in teaching practice more new knowledge and new skills, make the trained talent more professional.

The era of information, the task of cultivating talents in higher normal is getting heavier and heavier, preschool education and basic education, constantly extend and expand, in the practice teaching, according to the cultivation of qualified the basic direction of the basic education of excellent teachers, continuous reform and perfect the education plans and measures, make the dance teaching pace faster keep up with The Times development, produce more for the society more professional and high-quality talents in the field of dance education.

\section{The Present Situation of Higher Normal Dance Course Teaching}

\subsection{The Teaching Materials and Class Schedules Used in the Higher Normal Dance Course are Unreasonable}

Teaching materials are the main basis of teaching activities, and the rationality of teaching material structure is directly related to the teaching quality and the realization of teaching objectives. For the students, teaching material is the main basis of learning theory knowledge, but most of the current higher normal dance teaching lack of standardized textbooks, higher normal dance teaching using the teaching materials are in use is dance professional colleges and universities teaching materials, teaching content from the requirement of the dance teaching theory, is not conducive to normal dance lessons to the cultivation of talents. Higher normal dance course scheduling, generally is two hours every week, this arrangement allows students' dance lesson time interval is too long, bad for students to consolidate the knowledge, cultivating dance learning ability. Higher normal dance training courses teaching content are mostly simple form and some representative national dance, the higher normal students, even if can master the dance movements within the limited class hour, understand the cultural background of the kind of each dance, it is difficult to grasp each kind of posture rhythm dance, more can't be in into jobs will dance movements full enough to students.

\subsection{The Curriculum Setting is Not Consistent with the Training Objectives}

The establishment of education professional courses in higher normal university is mainly based on the education and psychology degree, and the lack of professional dance managers leads to a lot of drawbacks in the teaching of higher normal dance teaching. The dance course lacks a scientific teaching plan, and the dance classroom is called what students learn, which is contrary to the theory of dance teaching.

\subsection{There are Two Extremes of Professional Degree in Dance Teachers}

The teachers of higher normal dance courses are mostly music professional dance teachers, this practice for the higher normal colleges and universities to save personnel, but also to the higher 
normal dance teaching brought disadvantages, dance teachers or professional ability is not enough, to pattern dance professional too strong, This kind of professional degree two division's malpractice will increase the professional teacher high request and the student low ability contradiction, does not favor the higher normal School student's study and the ability training.

\subsection{The Students' Own Conditions are Limited}

Dance is a kind of behavior art through the movement of human body as a means of expression. The standard and graceful nature of dance movements directly affects the viewer's feelings. There are many students of higher normal School have not received professional dance training, and higher normal students due to age, bone development has been stereotyped, plasticity is not high, therefore, many students cannot be precise, graceful use of dance body language for emotional expression.

\subsection{Lack of Clear Teaching Objectives}

At present, many teachers colleges in our country have not developed the teaching content and teaching plan based on the characteristics of dance teaching, the teaching content of dance and the function of teaching plan are used to let students contact and rough understand some basic dance knowledge, students dance quality is uneven, imitation and dance expression is poor, These disadvantages seriously limit the creation of dance. The setting of dance teaching mode of higher normal education must focus on the professional characteristics of dance curriculum, so as to highlight the subject thought of the new curriculum.

\subsection{The Backward Teaching Method Restricts the Students' Interest in Learning}

Most of the dance teachers in the higher teachers ' College come from the professional dance school, the systematic study of the professional dance theory knowledge and skills, in the teaching process is susceptible to their own influence on higher normal students have high expectations. Some young teachers who have just come into work are eager to make achievements in the work, the arrangement of the dance is too difficult, many students are difficult to accept, the traditional dictation method is too simple, it is easy to let students lose their interest in dance learning. There are many students in the higher Normal school who have not studied dance specially. More is from the TV and network contact dance, in the watch dance clips More is pastime, considering not to the stage of the next ten years of work, in the study of dance often will feel boring, coupled with the beginner when the action is difficult to coordinate, and around the students who have learned the difference between dance, it is easy to dance knowledge and skills lost interest in learning. Students in the limited class cannot fully grasp the dance knowledge and skills, under the class there is no standard action for reference, in the absence of correct guidance, with the increase in learning content, students of dance knowledge and skills of learning interest will be smaller.

\section{The Reform Path of Teaching Mode of Dance Teaching in Normal Universities}

\subsection{Set up Correct Dance Teaching Idea}

Influenced by examination-oriented education, the idea of cultural quality and light artistic accomplishment is deeply rooted in many educators ' thoughts, which restricts the popularization and development of dance education to a large extent. Higher normal dance teaching is an important content in the training of preschool education and middle school, teachers must realize that dance learning has an important positive effect on cultivating students ' aesthetic cultivation, forming thinking in images, enriching the spiritual world, stimulating innovative consciousness and promoting the healthy growth of young children and adolescents. To correctly understand the role and status of dance teaching in training more qualified teachers, teachers of higher normal education should pay more attention to the teaching of dance course, take dance teaching as an important content in the cultivation of talents, deeply carry out the exploration of dance course construction and teaching mode. 


\subsection{Strengthening the Construction of Teachers' Team of Dance Teaching in Normal Universities}

Most of the teachers in dance course are graduates of dance majors, they have good dance professional quality, but the dance teaching idea and teaching skill are not in accordance with the requirements of higher teacher dance curriculum for talent training. Many dance teachers without systematic education and psychological training, in the teaching methods and content selection on the very strong randomness, teaching practice also did not take into account the actual situation of students and curriculum teaching objectives, knowledge blindly continue to their own teachers to adopt the teaching methods, This has caused great hindrance to the smooth implementation of dance course teaching in normal University, and it is necessary to continuously improve the teaching level and improve the teachers' training. In practice teaching is based on the number of classes and dance courses set up with the appropriate amount of dance teachers, in addition to the dance teachers on a regular basis of education and psychological training courses to improve the dance teacher's educational skills, so that dance teachers in practical teaching in accordance with the goal of cultivating reasonable teaching content and teaching measures.

\subsection{Rational Development of Teaching Materials of Dance Course}

The teaching material has the vital function in the practice, is the curriculum goal and the teaching content concrete manifestation, is also carries on the teaching activity the important tool, the supporting teaching material is vital to the higher normal school talented person training goal realization. The development of teaching materials for dance courses in normal universities should only focus on the characteristics and teaching objectives of dance courses of different educational majors, the contents of teaching materials should be related to professional basic knowledge and basic skills, according to the training objectives of different majors, remove those content which is more difficult and requires higher technical requirements. The preparation of textbooks is a highly professional work, the writer of the textbook should not only have a good professional and research ability, but also have rich teaching experience and high level of writing, in which the higher teacher dance course can take the form of collective development in compiling dance textbooks, With the help of the wisdom of the group, the author prepares the advanced Teaching materials of dance course, and strives to compile the teaching materials of pertinence, scientificity and feasibility, and to promote the construction of the dance curriculum model of higher Normal School.

\subsection{Constructing a Dance Teaching Model of Feasibility and Adaptability}

The teaching mode of dance course which accords with the training goal of higher teacher education has important practical significance and high theoretical value to train qualified talents. The aim of talent training in higher normal education is to train the excellent teachers in general section, this requires students in addition to master the professional knowledge of various disciplines, but also should have a sound, body, beauty, dance and many other professional abilities, but the dance majors in normal colleges and universities dance majors and dance professional college students dance ability requirements are different, The object of higher teacher education is young children and young students, the goal of dance teaching is to inspire and train them to set up correct aesthetic consciousness and aesthetic emotion by guiding their children to use body language to describe their life and express their feelings, and to inspire students ' enthusiasm for dance learning and creation. The key point of the teaching of dance course is to cultivate students' dancing interest, aesthetic ability, dance performance and composing ability. In view of this, the teaching model of Dance course in normal University can create "four-stage teaching mode" according to the theory and characteristics of dance teaching, the first stage of the teaching content is to enable students to appreciate the dance works, teaching dance basic knowledge, to cultivate and improve students' aesthetic ability and aesthetic taste, stimulate students' interest in learning; then into the second stage, By imitating dance movements to guide students to master dance skills, in this stage, it is mainly to improve the students' coordination ability, to help them to shape good physique and temperament, 
and to strengthen the students ' dancing skills. After the third stage of the teaching, students will be guided to the dance of their understanding of the work of dance moves, give action emotion Finally, it is to carry out dance teaching and learning, training students to dance elements of the comprehensive use of the ability and emotional expression.

\section{Conclusions}

Under the time background that dance education in higher normal universities has rapid development, higher normal dance education workers must update their education ideas, clear dance teaching ideas, innovative dance teaching method, create a set of teaching and adapt to the characteristics of the higher normal dance teaching mode, the society and the quality education of higher normal job requirements, to truly implement the dance teaching practice, dance with scientific and reasonable teaching mode developed more high-quality education talents, promoting the continuous development of education cause in China.

\section{References}

[1] Cao Jing. Study on strategies for enhancing the effectiveness of education in college dance, Journal of Hetian Normal College, 2010, 03.

[2] Shi Hongling. Study on the practicability of the training of education dance courses for normal preschool students, PopTimes, 2016, 06.

[3] Chen Ming. Study on "imitation - practice - inquiry" mode of professional dance teaching of music, popular literature, 2013, 03.

[4] Jin Yue. The mutual praise of higher normal preschool teaching is also explored in the reform of dance teaching, Liaoning Normal University, 2014, 09.

[5] Xu Yunyun. Construction and implementation of education professional dance course system in normal primary school, Hunan Normal University, 2012, 06. 